\title{
A favor da insubordinação
}

\author{
Transparências da memória: \\ estórias de opressão. Diálogos \\ com a poesia brasileira \\ contemporânea de autoria \\ feminina.
}

SOARES, Angélica.

Florianópolis: Editora Mulheres, 2009.

Em 1999, Angélica Soares nos brindou com A paixão emancipatória. Vozes femininas da libertação do erotismo na poesia brasileira, a que vem se juntar este livro sobre a memória e as histórias de opressão na poesia brasileira de autoria feminina. Existe um feliz parentesco entre essas duas obras, pois ambas, além de trabalharem com um corpus da mesma natureza, se empenham na desconstrução de certos paradigmas da ideologia patriarcal. E o fazem de forma libertária, através da leitura de poemas selecionados, leitura que evidencia pontos de tensão do universo feminino.

Antonio Carlos Secchin, em Poesia e desordem, caracteriza a poesia como um espaço de insubordinação. Segundo ele,

Ela deve ser a palavra vigorosa diante de todo arbítrio classificatório, a pulsação discursiva que não se pode catalogar senão nas margens. Por isso, a poesia representa a fulguração da desordem o "mau caminho" do bom senso, o sangramento inestancável do corpo da linguagem, não prometendo nada além de rituais para deus nenhum.

É tão grande a familiaridade de Angélica Soares com a linguagem poética, que esta se faz presente através de ressonâncias em seu texto de prosa. Daí o prazer que a leitura de seu livro nos proporciona. Esse prazer provém também, da forma com que ela organiza o livro, em módulos que, na sua diversidade temática compõem uma arquitetura perfeita. Após um texto introdutório sobre questões presentes no "memorialismo poético", no qual ela traça seu objetivo - "buscar diálogos possíveis com textos poéticos selecionados, que me permitissem introduzir a permanente tensão entre lembrar e esquecer, pensada aqui como um dos pilares de nosso dinamismo existencial" (p. 13) -, ela reúne em cinco capítulos os resultados obtidos através do diálogo com um grupo seleto de poetisas. É importante notar que esses resultados, isto é, os temas decorrentes dessas leituras, brotam dos poemas sem a interferência sufocante de teorias. É lógico que o substrato teórico é sempre uma bagagem necessária, desde que não atrapalhe. E aqui lembro as palavras de Tzvetan Todorov, em A literatura em perigo: "Para erguer um prédio é necessária a montagem de andaimes, mas não se deve substituir $\circ$ primeiro pelos segundos: uma vez construído o prédio, os andaimes são destinados ao desaparecimento". ${ }^{2}$ Como acontece com a teoria.

O diálogo com textos poéticos de autoria feminina vai suscitar várias questões - relação entre tempo e memória, em textos de Cecília Meireles; essência do habitar, em Adélia Prado; exercício metamemorialístico, em Marly de Oliveira; essência temporal da realidade, em Helena Parente Cunha; recriação lírica da recordação, em Astrid Cabral; transcendência indizível da palavra poética, em Arriete Vilela; indissociabilidade entre tempo e espaço, em Renata Pallottini. Isso tudo no primeiro capítulo que trata dos "ilimitáveis da memória".

Segue-se outro capítulo sobre questões de gênero e exclusão das mulheres, a partir de Teresa de Lauretis. Aqui encontramos reflexões 
sobre poemas de Adélia Prado, Silvia Jacintho, Astrid Cabral, com destaque para a consciência da opressão feminina.

Num terceiro momento, o capítulo se abre com uma reflexão sobre identidade e memória que vai ser pontuada em textos poéticos de Helena Parente Cunha, Myriam Fraga, Lara de Lemos, Lya Luft, Hilda Hilst e Marly de Oliveira.

O quarto capítulo, "Reconstruindo a solidão infantil", apresenta, inicialmente, um texto sobre memória como testemunha da opressão na infância. E aqui temos diálogos com Marly de Oliveira e Neide Archanjo.

E numa sequência que chamaríamos cronológica, o livro termina com o capítulo "Anotações sobre e envelhecimento das mulheres", que enfatiza, na abertura, a velhice como uma experiência radicalmente distinta para homens e mulheres. O diálogo com textos de Adélia Prado, Diva Cunha, Renata Pallottini e Alice Ruiz encerra o livro.

O título, Transparências da memória: estórias de opressão. Diálogos com a poesia brasileira contemporânea de autoria feminina, vale por um resumo, pois aponta para questões fundamentais que surgem dos diálogos com as poetisas contemporâneas. Como diz Constância Lima Duarte, na orelha do livro, Angélica busca "detectar os pontos de pressão que historicamente se repetem no cotidiano do universo feminino: a busca da identidade, a construção da memória, o envelhecimento". E o faz de forma poética, através do diálogo com poemas muito bem selecionados, mas sem perder a coragem, porque denuncia "o silêncio sobre a opressão", como diz Rosiska Darcy de Oliveira, no prefácio.

A bibliografia, ao final do livro, é vastíssima e extremamente valiosa aos pesquisadores dessa área. E as citações que permeiam o texto de Angélica têm o mérito de apontar para outras direções, mostrando que o livro não se limita às questões femininas. Por exemplo, Guimarães Rosa aparece falando das astúcias da memória: "Contar é muito, muito dificultoso. Não pelos anos que já se passaram. Mas pela astúcia que têm certas coisas passadas - de fazer balancê, de se remexerem dos lugares" (p. 121). Além de Rosa, Fernando Pessoa, Proust e outros, mas sempre em boa companhia.

Trata-se de uma obra imprescindível para os amantes da boa poesia de autoria feminina. Os iniciados terão acesso a um rico universo crítico-poético, nem sempre de fácil penetração para os iniciantes.

\section{Notas}

'Antonio Carlos SECCHIN, 1996, p. 18.

${ }^{2}$ Tzvetan TODOROV, 2009, p. 32.

\section{Referências bibliográficas}

SECCHIN, Antonio Carlos. Poesia e desordem. Rio de Janeiro: Topbooks, 1996.

TODOROV, Tzvetan. A literatura em perigo. Tradução de Caio Meira. Rio de Janeiro: Difel, 2009.

Elódia Xavier

Universidade Federal do Rio de Janeiro 